\title{
A antropologia, a mitologia e sua escrita
}

\author{
ORDEP JOSÉ TRINDADE SERRA \\ Departamento de Antropologia \\ Faculdade de Filosofia e Ciências Humanas \\ Universidade Federal da Bahia
}

\begin{abstract}
RESUMO: Este artigo trata de problemas relativos à definição de um conceito antropológico de mito e da aplicabilidade das noções de mito e mitologia na perspectiva de estudos transculturais. Chama-se aqui a atenção para a singularidade da "mitologia clássica" enquanto uma construção histórica particular, resultado da prática dos mitógrafos, e adverte-se a necessidade de distinguir entre "mítica" e "mitologia". Procura-se mostrar a importância dos estudos clássicos na configuração do horizonte da Antropologia. Discute-se a afirmação de Lévi-Strauss de que um mito é logo reconhecível como mito "por qualquer leitor do mundo"; sua apreciação da mitologia grega é comparada com a visão de um helenista, Eudoro de Sousa, que também se preocupou com a singularidade da mítica dos helenos. No interesse de esclarecer o sentido de "mito" como categoria antropológica, procura-se ainda reconsiderar a (moderna) oposição teórica dos conceitos de mythos e lógos.
\end{abstract}

PALAVRAS-CHAVE: mito; mítica; mitografia; mitologia clássica; antropologia; helenismo.

Antropologia não é nome grego. Trata-se de uma palavra artificial, forjada a partir do grego. No mundo heleno da Antigüidade, não se abriu o espaço semântico necessário para a criação desse termo. No entanto, uma coisa é certa: embora toda moderna, a Antropologia tem uma de suas raízes nos Estudos Clássicos. A investigação sistemática das civilizações antigas erigiu um referencial que muitos dos fundadores, muitos dos responsáveis pela construção e consolidação da Antropologia, nunca deixaram de considerar. A incessante reflexão do Ocidente sobre o mundo do helenismo preparou, influenciou e marcou a formação do pensamento antropológico'.

Neste artigo, tratarei de um elemento do legado "clássico" dos antropólogos. Os conceitos de mito e mitologia, que lhes servem de instrumento comum para a abordagem de fenômenos ideológicos oriundos do campo de diferentes culturas, refletem ainda sua história "clássica"... e a moderna que a redobrou.

Que dizem estas palavras? São apenas rótulos, já esvaziados de seu conteúdo antigo, prontos para uma aplicação "genérica?" Desapareceram de todo os seus antigos suportes? Terão deixado apenas fantasmas na consciência ocidental, já liberta de seu fascínio, e capaz de identificá-los como formas típicas (iguais a muitas outras, de diversas origens)? Em que medida isto é possível? Qual o estatuto dos mitos gregos no Ocidente? 
No âmbito da chamada "civilização ocidental”, os mitos da Antigüidade Clássica não se apresentam do mesmo jeito que quaisquer outros, oriundos de "domínios" distintos. Eles têm uma vida singular no Ocidente.

Esta afirmativa que acabo de fazer parece esboroar-se ante uma convicção irredutível: tende-se a tomar a crença declarada como a prova real da vitalidade dos mitos ${ }^{2}$. Ora, já nenhum culto corresponde aos velhos mitos helênicos... Eles hoje não constituem, em parte alguma do mundo, artigo de fé, ou matéria de religião. Há muito se proclamou a morte de Pã, e os deuses do helenismo nem mesmo se vêem contestados... Envolvidas por franca e tranquiila descrença, as "histórias sagradas" da Antigüidade Clássica se dessacralizaram, e perderam a autoridade do consenso fiel. A convicção generalizada a seu respeito não lhes dá respaldo.

Ao contrário, é negativa.

No Prefácio de um compêndio muito popular de "mitologia grega", o autor observa que os mitos gregos são... évidemment, des mensonges...

O curioso é que esse autor não se deu conta de um problema posto por seu esclarecimento. Não lhe passou pela cabeça uma questão crucial: como é que mentiras cuja falsidade já se tem por demonstrada há séculos, ainda assim não se apagaram da memória coletiva, não desapareceram diante da certeza adversa? Se sua pretensão à verdade, e até à verossimilhança, foi desmoralizada, porque os mitos gregos não foram esquecidos? Porque esses mitos foram conservados, sendo rejeitados?

Uma resposta comum (e insuficiente, apesar de tudo) cifra-se em lembrar que eles tiveram, em seu novo contexto, uma segunda sagração: esta, poética.

O processo iniciou-se na Antigüidade Clássica, onde a arte bem cedo se apropriou dos mitos.

Será verdade que ela os transplantou, sempre de modo a desnaturá-los?

Os gregos jamais concordariam... Eles atribuíam a poetas a criação de sua mitologia, que creditavam a Homero, Hesíodo, Orfeu...

É mesmo frágil a tese de que o converter-se de hieroi lógoi na forma poética, no mundo antigo, significou sua dessacralização. Se o pode sugerir uma leitura de Ovídio, basta uma mirada à Teogonia para que se pense o contrário ${ }^{3}$. Ainda assim, a idéia de uma "mutação poética" da mítica não deve ser abandonada sem maiores considerações. No caso dos gregos, a pergunta sobre o fundamento da aceitação dos mitos, o motivo de sua sobrevivência para além do horizonte religioso, é ainda passível de colocar-se como um outro aspecto de um problema "goetheano": o das relações entre... Dichtung und Wahrheit.

A ruptura do compromisso com a crença pode até ter ampliado o alcance dos mitos helênicos no Ocidente: "abrindo-os", com maior franquia, a novas formas de pensar. Assim, eles prestaram-se à construção de novos modelos de realidade, e desenvolveram outras metamorfoses, também poéticas. Disto se infere a renovação de seu potencial cognitivo: a poesia tem eficácia reveladora, pois torna fantasticamente livre o jogo do conhecimento. Recorde-se o dito de Nietzsche sobre o privilégio do "único que pode mentir"4.

Os mitos helênicos acham-se no amálgama dos saberes esquecidos que alicerça, no terreno da Urdoxa, os nossos edifícios teóricos, muitas de nossas construções simbólicas. Como diz George Steiner (1986), a mitologia dos helenos teve um papel decisivo na instauratio magna da consciência ocidental, mesmo porque, "do ponto de vista do espírito... o Ocidente ainda fala grego".

Neste novo domínio por onde se espraiaram, os mitos da Hélade não se encontram reduzidos a adornos retóricos, ou a motivos tradicionais nas artes plásticas, segundo pode 
parecer a uma mirada superficial. Tampouco ficam, na consciência moderna, cingidos ao espaço erudito, ilhados por um saber que os neutralizaria. Não estão imóveis: marcando profundamente o nosso imaginário, fluem com energia em diversos circuitos. Por notável exemplo, ao longo da história do pensamento filosófico eles têm constituído um campo de referência sempre revisitado, e dotado de fortíssimo apelos.

É certo que esses mitos não "vivem" agora como "viviam" no orbe do helenismo... entre outras coisas, porque os gregos não mitificaram a sua mitologia como nós a mitificamos. Na modernidade, os mitos helenos habitam uma nova tradição, assentada em espaço ideológico diverso do que constituía seu antigo domínio. Têm neste nicho novas articulações e usos, assumem sentidos que não possuíam.

Vivem outra vida.

Estão, ao mesmo tempo, muito perto e muito longe de nós.

Steiner pode ter razão quando diz que, do ponto de vista da inteligência., o Ocidente ainda fala grego. Mas dificilmente os gregos antigos reconheceriam esta "fala" que constitui seu legado...

Seja como for, a mitologia grega ocupa um lugar de destaque no imaginário do Ocidente. Aos olhos de muitos, ainda é a mitologia por excelência. Quando nada, por séculos o foi... Até mesmo o fato de que seu conteúdo se separou com nitidez do campo religioso, da crença religiosa, contribuiu para torná-la um espaço privilegiado, um tesouro de imagens ao qual se tornou costume recorrer na especulação de verdades que a transcenderiam por princípio: ela tornou-se a grande seara alegórica com cuja matéria se vieram a fazer símbolos novos, em destacados projetos poéticos, ou filosóficos.

Viu-se ainda a mitologia grega como uma espécie de clareira, excepcionalmente luminosa, no emaranhado universal da fábula, de que ela representaria uma forma superior - na perspectiva, está claro, do etnocentrismo helenófilo dos ocidentais, para quem a Antigüidade Clássica é o passado "maior", definitivo em muitos sentidos, e o mais original: marca a fundação da humanitas, uma rica epifania da essência do humano. Até mesmo em Marx se percebe um encanto nostálgico pela "infância grega" da humanidade... A rigor, são incontáveis as obras que respiram esta nostalgia. No campo da arte e da literatura, em momentos decisivos da criação do Ocidente (do mito do Ocidente), manifestou-se o fascínio pela mítica dos "antigos"... Tornou-se mesmo um lugar comum a evocação da inocência pagã encarnada nas legendas clássicas. Freud não foi insensível a esse apelo... ${ }^{6}$

Evocarei agora um momento decisivo em que a reflexão antropológica se mostrou marcada de um modo vigoroso pela mitologia "clássica" e pela tradição erudita relacionada com ela.

O momento é decisivo porque representa um dos mais poderosos ensaios de abordagem do mito numa perspectiva "universal".

Não é do velho Frazer que vou falar... Quero referir-me à obra de um grande "mitólogo" contemporâneo, um dos maiores nomes da Antropologia do nosso tempo.

Lévi-Strauss protestou que "um mito é percebido como mito por qualquer leitor, no mundo inteiro" ". De um modo sub-reptício, esta sentença impõe uma condição prévia que limita a possibilidade da identificação suposta: nessa perspectiva, mito será sempre (res) 
legenda: coisa escrita, ou passível de escrita. Embora mitos sejam abundantes em sociedades ágrafas, Lévi-Strauss não garante que um mito seja reconhecível por qualquer analfabeto no mundo inteiro... ${ }^{8}$

Não sei se existiria um intento oculto por trás da velada restrição. Talvez o autor quisesse demarcar assim o espaço onde a identidade do mito há de decidir-se. Nesse caso, ele circunscreveria a possibilidade do reconhecimento do mito qua mito a domínios onde o registro escrito já assinala a operação de distinções inusitadas antes da letra: onde a presença do legível reflete uma nova experiência do legítimo, e com isso já se tem operado um novo recorte no interior do verbo - um recorte que permitiria, justamente, opor o mito a um outro dizer.

Nesta hipótese, Lévi-Strauss seguiria uma trilha aberta por filósofos e historiadores antigos. Como Tucídides, por exemplo.

Cabe outra suposição, compatível com a primeira: inconscientemente, o antropólogo reportou-se ao paradigma de uma mitologia que se constituiu em Literatura: a mitologia clássica... tal como a erigiram os primeiros mitógrafos, logógrafos, mythologoí.

Já se observou que é duvidosa a possibilidade de traduzir com segurança o termo mito em grande número de idiomas. Nada garante que se ache sempre este conceito em outros domínios culturais, em sociedades de qualquer parte do mundo. Não é certo encontrálo onde quer que se verifique a existência de relatos classificáveis assim por um leitor ocidental. Que acontece quando pensamos um universo de narrativas "tradicionais" de uma cultura "exótica" circunscrevendo-o e delimitando-o como uma mitologia?

É difícil esquivar uma hipótese incômoda: quando nós falamos, por exemplo, em "mitologia kamayurá" (ou nagô, ou hindu etc.), pode ser que nos estejamos movendo, inconscientemente, no espaço moderno desenhado por uma interpretação do "mundo antigo", numa perspectiva aberta ao longo do trajeto em que nos afastamos dele. Podemos estar "mitologizando" outras tradições, de acordo com uma tradição que nos acompanha, e aplicando um molde categorial pouco inocente no estudo de distintas culturas. Quem penetra neste campo conturbado, obriga-se a uma reflexão preliminar, em que deve indagar-se: $\mathrm{O}$ que representa a mitologia grega para o antropólogo? Será ela uma entre outras, uma como qualquer outra?

Lévi-Strauss encarou esta questão, embora de passagem. Recorde-se o capítulo final do segundo livro das Mythologiques, em que o americanista discorre sobre "Les instruments de ténèbres" ". Já nas últimas páginas do volume, ele adverte uma mudança no percurso encetado na primeira etapa de seu grande projeto. Nessa etapa, a fim de construir o sistema dos mitos de cozinha sul-ameríndios, ele trabalhou com oposições entre termos (quase todos) designativos de qualidades sensíveis, tipo cru e cozido, fresco e podre, seco e úmido, etc. Na etapa seguinte, eis que surgiram termos novos, ainda em pares de opostos, mas de outra natureza, pois já não concerniam a uma lógica das qualidades, e sim a uma lógica das formas: termos como vazio e cheio, continente e conteúdo, interno e externo, incluído e excluído. Ainda neste caso, os mitos procedem do mesmo jeito: traçando correspondências entre vários códigos, de forma simultânea. Por essa razão, vêm a assumir posição axial no sistema representações sensíveis que se correlacionam com objetos providos de uma pluralidade de funções, feitas homólogas no discurso mítico: pode-se assim viajar de uma para outra, num percurso já marcado pela abstração. Lévi-Strauss conclui:

Toutes nos analyses démontrent... que les écarts différentiels exploités par les mythes ne consistent pas tant dans les choses mêmes que 
dans un corps de propriétés communes, exprimables en termes géometriques et transformables les unes dans les autres au moyen d'opérations qui sont déjà une algèbre. Si cette marche vers l'abstraction peut être mise au conte de la pensée mythique (...), on conviendra que nous sommes parvenus au point où la pensée mythique se dépasse elle même et contemple, au délà des iamges encore adhérentes à l'expérience concrète, un monde de concepts affranchis de cette servitude et dont les rapports se définissent librement: entendons, non plus par reférence à une réalité externe, mais selon les affinités et les incompatibilités qu'ils manifestent vis à vis des autres dans l'architecture de l'esprit. Or, nous savons où un tele bouleversement se situe: aux frontières de la pensée grecque, là où la mythologie se désiste en faveur d'une philosophie qui émerge comme la condition préalable de la réflexion scientifique.

Talvez não esteja bem formulada a afirmativa de que, na Grécia, "la mythologie se désiste en faveur d'une mythologie”. No mundo helênico, filósofos se voltaram contra os mitos... mas não os fizeram desaparecer. O mito não se retirou quando o pensamento filosófico floresceu. Continuou vivo, até mesmo no seio do novo discurso. Por vezes, abraçou-se à teoria: recorde-se os Endmythen platônicos... Não há, pois, uma automática sucessão que instaure o no lugar do mito o lógos filosófico, substituído mais tarde pela Ciência.

Percebe-se que Lévi-Strauss então se inclina perante um paradigma poderoso: a "Lei dos Três Estados". Com os olhos postos neste paradigma, aponta um limiar que só uma vez se franqueou, uma possibilidade realizada apenas em uma ocasião histórica ${ }^{10}$. Segundo ele frisa, a passagem sempre fora possível, em qualquer parte. Mas só ocorreu dessa feita: no mundo helênico.

No caso sul-americano, que então o grande antropólogo aborda, evidentemente não houve o progresso rumo ao conceito puro (por suposto) anunciado nos desenvolvimentos míticos: aí não se chegou à Filosofia... nem, por meio dela, ao porto seguro da Ciência. Ainda assim, Lévi-Strauss confirma: o estudo deste caso abre caminho para a compreensão de problemas relativos à natureza e à evolução do pensamento humano. Pois se os mitos de culturas as mais atrasadas ("les plus arrièrées") nos defrontam com esse limiar decisivo da consciência humana - umbral que no Ocidente ("chez nous") lhe deu acesso à Filosofia, e em seguida à Ciência - uma conclusão se impõe: em todo o mundo, os "estados sucessivos" do pensamento já se achavam embutidos no mítico. Se o progresso apenas se verificou num caso, é que nada tornava, nada faz necessário esse desenvolvimento, "ici comme là"..."

Nesse ponto, uma pergunta devém inevitável: porque terá isso ocorrido (somente) na Europa?

Segundo Lévi-Strauss logo contesta, por conta de fatores múltiplos que correspondem à contingência irredutível da História. Ou seja: se contasse com o favor da História, a mitologia sul-americana resultaria em Metafísica, e em Ciência depois. O mesmo poderia ter acontecido com a mítica chinesa. Ou com a hindu. Ou com australiana... com qualquer outra.

Deduz-se: a mitologia grega eqüivale às demais...

... até certo ponto.

É interessante contrastar com a posição de Lévi-Strauss a de um helenista que também se ocupou da mesma passagem. Em diferentes estudos, Eudoro de Sousa tratou das relações entre a Mitologia e a Filosofia dos helenos. (Referiu-se apenas ocasionalmente a 
culturas dadas a conhecer pela Etnologia, embora não recusasse comparar com elas a helênica). Como Lévi-Strauss, Sousa rejeitava a tese de que os mitos (gregos ou de qualquer outra origem) transparecem uma mentalidade pré-lógica. Jamais pressupôs, tampouco, uma superioridade do equipamento mental dos helenos como explicação do advento da filosofia num mundo povoado de mitos. Num belo ensaio ${ }^{12}$, o helenista luso-brasileiro chamou a atenção para a impregnação poética do filosofar dos gregos, nas origens, e observou (p. 96) que, embora o propósito dos historiadores do pensamento filosófico e científico seja o de "separar decisivamente a filosofia da poesia", eles sempre acabam por convencer-nos do contrário, quando enveredam "pela demonstração de alguma interferência dos processo mítico e filosófico." Cita, a propósito uma observação de Werner Jaegger (1936:207-8), para quem "Die zeitliche Grenlinie, wo der Durchbruch des rationalen Denkens anhebt, ist schwer zu ziehen..." ${ }^{13}$ Sousa volta ao ponto num outro estudo em que sublinha o acerto de uma velha sentença: "Homero foi o educador da Grécia"... Como diz, malgrado os protestos de Heráclito, Xenófanes e Platão, o fato é que os poemas homéricos contêm, em germe, até mesmo a Filosofia em nome da qual estes pensadores condenaram a grande obra poética... De resto, "na copiosíssima bibliografia homérica" inúmeros estudos tornam manifesto que "a philomitía da epopéia jônica já denuncia uma preocupação filosófica - embora, talvez, só negativamente" em seu esforço de "eliminar, ou transpor em luminosidade olímpica, as tenebrosidades míticas do passado pré-helênico e do presente oriental. Sob este aspecto, Hesíodo mostrase, evidentemente, um poeta da escola..."

Este é um dos elementos da tese eudoriana. Mas há um outro que ele veio a delinear através de críticas a uma tendência inveterada na Altertumswissenschaft: a atitude hostil à comparação transcultural, posição de que se tornaram campeões grandes helenistas como Willamowitz Moellendorf. Embora condenando o que há de equívoco nesta perspectiva, Eudoro de Sousa procurou resgatar o que haveria de válido no esforço de pôr em destaque a inegável originalidade da cultura helênica:

Sem dúvida, com o povo grego nasce no mundo algo de essencialmente irredutível ao passado e ao presente mediterrâneo e oriental. Mas, ao que nos parece, um dos traços característicos da grande novidade que surge no mundo antigo com o tão celebrado surto da cultura grega, reside... na negação da componente mitológica de sua cultura. Este traço característico talvez seja uma herança peculiar do indo-europeu ao grego, como talvez seja esse um dos traços definitivos das culturas da Ásia que mais fielmente guardaram e promoveram o legado semítico. A cultura hebraica, com seu monoteísmo, é a-mítica, pelo menos desde os grandes Profetas do Exílio; a cultura helênica, com seu panteísmo, tende a sê-lo, mas por uma via de compromisso, através da qual vai fundindo e confundindo todos os mitos em um mito só - o mito do Homem, decerto o mais helênicos dos mitos gregos, senão o único mito grego ${ }^{14}$.

Em suma: de acordo com Eudoro de Sousa, a mítica dos helenos (a "mitologia grega", diz ele) vem a ser uma interpraetatio graeca de mitos pré-helênicos, interpretação que incorpora, desde o início, um fator de estranhamento, ponto de partida para o desenvolver-se de novas formas de consciência. Só que o processo não chega a acabar-se:

Se a mitologia pré-helênica tivesse sido, toda ela, interpretada e traduzida pelos gregos, isto é, se a mitologia clássica fosse, toda ela, poesia 
grega ou latina; e se a interpretação do pré-helênico pelo helênico, e a versão do não-grego em grego, tivesse chegado a completar-se, sem que essas operações, no fim, deixassem resíduo do irredutível e irreversível passado, jamais se haveria posto um problema da mitologia...

A tese eudoriana é muito rica. Levaria demasiado longe aprofundar aqui sua discussão. Vou apenas assinalar uma rápida convergência: embora tenha tomado outro rumo em sua reflexão sobre o mesmo problema, pelo menos uma vez Lévi-Strauss atribuiu singularidade à mítica dos helenos: quando observou que "os mitos gregos fazem, eles próprios, a sua análise estrutural"15.

Recuando ao ponto em que o antropólogo e o helenista se acham em aparente acordo, uma coisa parece bem marcada: não se pode negar que, como não aconteceu com nenhuma outra mítica, a grega foi envolvida por, ou veio a desenvolver, uma Metafísica (um pensamento portador de Metafísica) em cujo seio germinou o sistema da Ciência.

Evidentemente, isto não obriga a supor que a mítica dos gregos nada tem a ver com as de outros povos. Seria absurdo condená-la ao isolamento desejado por um inveterado etnocentrismo ocidental, helenófilo pro domo sua... ${ }^{16}$ Por certo, nos mitos gregos atua a mesma lógica discernível em mitos dos bororo, por exemplo. Acham-se neles esquemas recorrentes em diversas míticas. Mas o desenvolvimento histórico do sistema dos mitos gregos e o dos mitos bororo os conduziram por rumos que tornaram necessária uma diferença importante. Só o estudo comparativo, tornando reconhecíveis as analogias profundas entre os códigos míticos de diversas sociedades, pode abrir caminho a uma compreensão efetiva de características que distinguem uns dos outros. Afinal, não teria sentido dizer que, por exemplo, a mítica hindu, a nagô e a tupi em nada se diferenciam...

Afirmar que a mítica grega tem traços singulares não significa necessariamente atribuir aos helenos um privilégio absoluto. "Os gregos não são como os outros", os hindus não são como os outros, os nagôs não são como os outros... pelo menos em tudo. Ou não teríamos como falar em gregos, hindus, nagôs... et caeteri. Haverá traços na mítica de um povo que permitam singularizá-la, assim como em sua arte se encontram características idiossincrásicas. Não se nega a originalidade da cerâmica Waurá quando se afirma a da Kaduweo...

Volto à tese eudoriana. Esta é mais complexa do que parece. Não se reduz a uma simples contraposição do pensamento mítico dos gregos ao de quaisquer outros povos. Eudoro propôs a idéia de que os gregos reagiram de um modo singular à mítica por eles herdada de (e comungada com) outros povos. Mas não se trataria de uma reação completamente insólita. Os gregos teriam seguido um impulso comum a outros grupos, indo-europeus e semitas, na tendência da negação do mítico. Destacaram-se pela forma original como, ao mesmo tempo, o negaram e acolheram... transformando, a seu modo, essa "linguagem" arcaica. Seguindo o caminho aberto por Eudoro de Sousa, pode-se ver a mítica dos helenos como um processo, uma realidade complexa e dinâmica, que evoluiu abraçada a sua contradição, sempre tomando formas novas. O reconhecimento de que o mito grego moveu-se e reconfigurou-se de maneiras inéditas impõe-se a quem quer que considere, por exemplo, a originalidade de sua revolução trágica.

Por este rumo, é possível uma compreensão mais rica do fenômeno, sem recair no paradoxo do "grego de duas cabeças" que Detienne (Detienne, 1981:109-224) evocou num estudo famoso, onde também aborda as teses levistraussianas comentadas aqui.

Adiante voltarei a este ponto. Antes, assinalarei outra coisa que merece destaque: a mítica dos helenos deu lugar a uma mitologia, provocou uma mitologia. 
Para maior clareza, proponho que se distinga a mítica helena antiga da mitologia clássica. Esta é um fenômeno histórico tardio, muito tardio, se comparado com o surto dos mitos gregos. Os logógrafos erigiram as bases da nova construção, já bem estruturada no século IV a. C., mas nos primeiros séculos da nossa era é que se arrematou o edifício da mitologia, integrando antigas legendas num corpus idealizado como único, numa seqüência ordenada, em um conjunto a que se procurava dar alcance universal, feito pano de fundo da história que se queria comum.

Nesse contexto é que o mito aparece destacado enquanto um objeto específico ${ }^{17}$.

Embora não da mesma forma que tinha no Império Romano, a mitologia clássica está presente em nosso mundo. Deu origem a uma prática erudita que, desde a Renascença, vem ajudando a criar a identidade ocidental ${ }^{18}$.

Não é difícil encontrar estudos sobre mitos gregos em que eles são tratados como se tivessem chegado à existência já "em estado de mitologia".... o que dá a esses belos ensaios interpretativos a animação de uma caçada no zoológico ${ }^{19}$. O ponto de partida de semelhantes análises é um anacronismo curioso. Pois a "mitologia clássica" é um produto tardio, cujo acabamento e consagração se deram no mundo romano. É um acontecimento cultural do Império Romano. O processo de sua constituição teve início antes, é verdade: quando escritores helenos começaram a fazer um novo registro do corpus legendário de sua tradição. Já nas obras desses compiladores o estatuto dos mitos se alterava: os antigos logógrafos passaram a manejá-los de uma forma antes insólita, retirando-os de seu contexto poético e ensaiando reagrupá-los com uma nova ordem. A mitologia clássica vai surgir do processo assim iniciado, como fruto da mitografia. E o desenvolvimento da mitografia canaliza a corrente mítica em uma nova direção.

Buscarei mostrá-lo com uma breve ponderação, que só aparentemente desloca o assunto.

Segundo mostrou Havelock (Havelock, 1996), uma cultivada arte da palavra alcançou um extraordinário grau de elaboração na Grécia Antiga, muito antes de que houvesse aí uma literatura, no sentido moderno do termo: antes que a tradição escrita prevalecesse no campo da produção artística verbal, e constituísse seus cânones. Séculos e séculos de "oraliture" precederam a prática literária stricto sensu. A literatura "propriamente dita" é tardia: não apareceu logo que a escrita se impôs, assim que os textos poéticos começaram a ser grafados. Demorou muito mais a constituir-se.

Pois bem: do mesmo modo, o simples registro escrito de mitos não é ainda mitologia. Esta pressupõe desenvolvimentos complexos da prática mitográfica, sua configuração enquanto um campo erudito específico e a operação de distâncias que alimentam seu conato. O trabalho dos genealogistas vai abrir-lhe um espaço novo, no limbo da história; vai marcála uma nova sensibilidade estética, que os poetas alexandrinos inauguram, com seu interesse antiquário.

Na formação da mitologia vão intervir ainda um esforço voltado para a indicação do background preliminar da história acessível e o empenho na construção de uma referência cultural comum aos herdeiros da civilização helenística ${ }^{20}$.

Não tem menos importância neste processo o desejo de tornar explicável (e aceitável, em novos termos) a matéria mítica: inspirou os estudiosos antigos empenhados na construção de um novo saber dos mitos, orientou seu trabalho de compilação, presidiu ao erigir-se da estrutura do novo domínio ${ }^{21}$.

É preciso reconhecer a singularidade histórica da formação a que se chamou de "mitologia clássica". 
O constante reflorescimento das tradições eruditas que ela suscitou também teve um papel significativo na produção de estilos de pensamento.

A abordagem antropológica dos mitos de diversos povos tem este background, mais ou menos consciente.

E é melhor que o advirta.

Volto agora ao ponto crucial que assinalei mais acima, quando evoquei as reflexões de um antropólogo e de um helenista sobre a mítica dos gregos. Apesar de uma coincidência parcial, os dois autores evocados divergem bastante. E o helenista se mostra muito menos "helenocêntrico".

Observa Eudoro de Sousa que os mitos gregos (em geral herdados de, ou compartidos com, outros povos) distinguem-se pela maneira como vieram a ser tratados na cultura dos helenos, onde foram, a um tempo, acolhidos e estranhados... com um estranhamento que desembocou na Filosofia. Já para Lévi-Strauss, os mitos gregos "fazem sua própria análise estrutural" e chegam ao ponto em que a fronteira mítica vem a ser "naturalmente" ultrapassada. Digo naturalmente porque, na teoria do mestre estruturalista, esta ultrapassagem é uma possibilidade inerente aos mitos de todo o mundo, e só o azar da História fez com que isto acontecesse apenas uma vez, tão só na Grécia Antiga. Ora, sem dúvida os privilegia quem atribui aos mitos gregos a potência auto-analítica e os situa no instante de uma transformação cognitiva sempre possível... mas não automática... na qual, como se implica, se passou do menos ao mais: assim, de um modo indireto, o antropólogo acabou por conferir-lhes uma posição singular e um especial interesse para o estudo da criação mítica. É minha a inferência, mas ela parece-me ineludível: ali onde uma decisiva potencialidade de uma classe de seres chega à iminência da realização (pensada esta como uma Aufhebung), por certo adverte-se melhor sua estrutura, a constituição última, a natureza dos entes que integram a classe toda: a subclasse assim destacada há de ser a mais esclarecedora para quem estuda o conjunto maior. Embora Lévi-Strauss não o diga expressis verbis, deduz-se de sua colocação que a mitologia grega representa um marco decisivo: um marco que os antropólogos devem por força considerar, no estudo das míticas em geral.

Segundo Lévi-Strauss, os mitos nada ensinam sobre o mundo ou o homem. Mas isto não se deve a uma insuficiência lógica. Eles não são pré-lógicos. Ao contrário. De acordo com a teoria estruturalista, cabe até dizer que tudo quanto desvelam os mitos vem a ser sua própria lógica, na rede tautegórica em que se referem e significam uns aos outros. Nesta perspectiva, lógica é tudo que eles têm. Não possuem conteúdo positivo...

Mais uma vez, vale lembrar: segundo este sábio, existe uma via de mão única para o conhecimento: a ciência, a que o espírito humano chega passando primeiro pelos mitos, depois pela filosofia. Esta colocação tem valor axiomático para Lévi-Strauss.

Por trás do axioma, acha-se uma velha oposição que estudiosos do século passado esmeravam-se em traçar, recorrendo a palavras gregas ressemantizadas de acordo com seu projeto: a oposição de mythos e lógos.

No grego antigo, as palavras mythos e lógos compartiam muitos significados, eram equivalentes em diversos contextos. Não se opunham do jeito como acontece no discurso moderno. Segundo observou Marcel Detienne (Detienne, 1987, 66), só ao cabo de um desenvolvimento histórico-semântico que durou largo espaço de tempo, entre o século VI e o início do IV, mythos veio a designar "o discurso dos outros, que a fílosofia, apenas nascida, mas já escandalizada, aponta com o dedo e denuncia ruidosamente.” O uso novo de mythos veio a consagrar-se ao longo do século V. Detienne (op. cit., p. 61) assinala a obra de Tucídides 
como o lugar de uma fratura significativa: aí são nitidamente separadas uma da outra a tradição oral e a escrita, ao tempo em que a filosofia platônica vem a banir "poetas e artesãos dos lógoi, proscritos com todo o aparato do que seus contemporâneos chamam de arqueologia ou mitologia". No começo do século IV, pela ação convergente do saber histórico e do filosófico, "o que vinha sendo furtivamente designado como mito apagou-se, desapareceu, para fundir-se em nova paisagem". Abriu-se o espaço para a constituição da mitologia, no campo de uma nova prática letrada: "a dos mitógrafos, já profissionais" 22 .

Que vale a oposição mythos x lógos? Que é feito desses conceitos modernos, hoje?

Com discreto reconhecimento, Vernant (Vernant, 1996) registra o crédito hoje alcançado por uma tese cortante: "le mythe n'existe pas..." nada mais vem a ser que "...une construction en grande partie arbitraire des anthropologues."

Ora, é o caso de perguntar: como os antropólogos chegaram a isso?

O helenista explica: "utilisant un terme déjà chargé d'ambigüité par sa longue histoire depuis la Grèce ancienne, ils se sont fabriqué un domaine d'investigations dont les limites sont floues et dont l'objet, faute d'être spécifique, échappe à toute définition précise..."

Vernant assim retorna, com Detienne, à denúncia da simplificação produzida pela oposição de mythos e lógos feita em bases artificiais pelos estudiosos modernos.

É certo que ainda no mundo grego, com os progressos da Filosofia e da História, uma fronteira veio a ser demarcada entre essas palavras (mythos, lógos), quando se passou a usar a forma mythos para designar "o discurso dos outros, caracterizado como inverossímil, absurdo"... Porém então (pondera Vernant) mythos vinha a ser um termo vago, aplicado a um conjunto definido apenas negativamente, usado para indicar certos resíduos da tradição, "tout un bric-à-brac d'on-dits traditionnels, venus du fond des âges et transmis de bouche à oreille sans qu'on songe à les soumettre à la critique..." Na massa desse modo repelida e rotulada, não se vislumbra qualquer unidade... Limita-a apenas uma circunscrição negativa, estabelecida pelo arranque de um novo estilo de pensamento, pela recusa embasada nos critérios novos de quem constitui arrazoados, exige provas e confirmações - e ipso facto condena a inverossimilhança dos multifários discursos da tradição.

O momento helênico que Vernant destacou (aquele no qual um novo uso de mythos veio a ser índice de uma marginalização de discursos tradicionais) é bem o que evocavam os estudiosos modernos empenhados, no século passado, em fundar um novo saber dos mitos.

Está claro que existem diferenças consideráveis entre os dois momentos. O contexto no qual, na Grécia Antiga, mythos tornou-se um rótulo aplicável a diversos dizeres encontráveis no conjunto heteróclito da tradição proscrita por um novo discorrer (com uma estrutura de arrazoado) não é o de sua "recapitulação" moderna.

Mas a correspondência não é de todo infundada.

Tanto num espaço histórico quanto no outro, dá-se a irrupção de uma determinação excludente que distingue entre domínios assinalados como negativo e positivo, de um modo unilateral, do ponto de vista de um conhecimento que exige comprovação e razoabilidade.

Outra coisa é preciso reconhecer. Se tomamos o termo mythos "em estado de dicionário" (ou nos reportamos ao momento em que, no mundo helênico, uma nova maneira de pensar o reserva para a designação de tradições postas entre parênteses de suspeita), ficamos logo espantados com a variedade de objetos a que se aplica este nome. Mas há um momento "epistemológico" (um "lugar histórico numa episteme, no sentido foucaultiano), em que mythos adquire, no mundo antigo, um sentido muito particular.

Isso não ocorre porque então o termo se veja laboriosamente redefinido, num léxico novo; sucede por obra de uma prática erudita que realiza esta significação. 
Refiro-me à prática dos mitógrafos e a seu último resultado: a mitologia.

O sentido de mythos fundado por essa prática erudita é já o que terá mito no mundo moderno. Quando uma pessoa educada ouve ou lê esta palavra, pensa logo em narrativas que não são passíveis de comprovação, mas, apesar de improváveis, merecem (ou mereceram) um acatamento especial por parte de povos inteiros, de grupos humanos significativos; que foram ou são, reputadas memoráveis, embora incorporem elementos em contradição com a experiência comum (ingredientes fantásticos); que geralmente se relacionam com o domínio do sagrado, reportam-se a um tempo remoto, têm protagonistas extraordinários... como as antigas histórias gregas de deuses, semi-deuses e heróis, de catábases e metamorfoses.

Tem uma raiz histórica o senso comum a que Lévi-Strauss apelou quando disse que qualquer leitor, no mundo inteiro, reconhece um mito enquanto mito. Esse leitor há de ter no seu repertório a palavra grega mito, transposta em seu vernáculo... mais a noção que a acompanha desde o triunfo da mitografia como uma prática erudita específica.

Detienne (Detienne, 1981, p. 223-224) afirmou que “aujourd'hui comme hier... il n'y a pas de mythologie pensable sans réference... au discours tenu par les Grecs..." E enfatizou: "Parler de mythologie c'est toujours parler grec ou depuis la Grèce, à son insu peut-être, mais au risque d'être assigné à résidence perpetuelle en ce lieu ou les illusions des modernes sur la mythologie redoublent le fantômes et les fictions produits par les premier mythologues".

O "hier" a que remonta a primeira frase corresponde a meados do século XIX, quando surgiu o projeto de uma Ciência dos Mitos, acalentado em prestigiosas cátedras européias. Os idealizadores deste novo saber queriam dar-lhe um alcance universal, mas tinham a mitologia grega no foco de sua atenção. Perturbava-os o escândalo dos mitos gregos, e foi por aí que eles começaram sua tentativa de explicar a aparente irracionalidade dos mitos de diversas origens.

Ora, este destaque dado à mítica dos "antigos" não foi gratuito, nem coisa do momento em que a Ciência dos Mitos viu-se anunciada. Refletiu a presença de uma tradição erudita que, ao longo de muitos séculos, vem-se ocupando da mitologia clássica, empenhando-se em explicá-la, interpretá-la, entendê-la... e dar-lhe empregos múltiplos: retóricos, filosóficos, científicos, políticos etc.

Mesmo o escândalo inaugural que Max Müller, Andrew Lang, Decharme, Tylor et coeteri assinalaram como motivador da nova empresa científica (de estudo dos mitos) ecoava outros, muito mais velhos: tinha por trás de si uma rica história de denúncias, questionamentos e estranhezas, que começaram no mundo antigo, com a crítica filosófica, e prosseguiram (em outro registro) com os apologetas do cristianismo, mas foram muito além... Seus variados lances marcam toda a história da Altertumswissenschaft.

Enfim, uma coisa se mostra inegável: se o mito é, como Vernant admite, "en grande partie, une construction arbitraire des anthropologues", deve-se reconhecer que os antropólogos trabalharam nesta seara com instrumentos herdados dos estudos clássicos: os helenistas os precederam e iniciaram, foram seus mestres e precursores, neste particular.

Por certo, os helenistas têm consciência de que "falam grego" quando discorrem sobre mito e mitologia. Mas será que isto os livra da espécie de prisão descrita por Detienne, e dos fantasmas de seus edificadores? Será que ficam imunes ao feitiço de seus antepassados mythologoí? Conseguem realmente escapar desse local fantástico? Ou será que aí se sentem em casa? Isto os tornaria os mais iludidos dentre os cativos... 
A oposição de mythos e lógos é uma construção teórica. Não corresponde a uma descrição de categorias semânticas que já se achariam estabelecidas desde sempre, nitidamente demarcadas nas matrizes da língua, na tradição helênica do discurso. Não descreve uma estrutura paradigmática dada a priori nas origens da cultura grega, nem corresponde a uma constante praxe lingüística tradicional. Sem dúvida... Mas até aí não se tem um motivo fatal de plena rejeição. O fato de não ter correspondência com usos consagrados $a b$ origine, ou com paradigmas fixados de uma vez por todas na história dos nomes, por si só não invalida a proposição teórica que se vale desses termos na tentativa de descrever campos do discurso. É preciso julgar sua validade cognitiva no terreno da teoria, no hic et nunc da teoria.

Essa antítese se revela muito problemática quando pensada do modo como se cristalizou no discurso dos sábios do século passado empenhados na construção da "Ciência dos Mitos". Tem baixo rendimento cognitivo e promove equívocos. É mesmo preciso abandonar a oposição de mythos a lógos que refere ao primeiro termo os produtos "irracionais" da mente humana (os excessos da "louca da casa"), e adscreve ao segundo os enunciados da razão.

Mas talvez a distinção possa ser reutilizada de um modo produtivo.

Sugiro um meio: cabe referir à aura do lógos uma ênfase na potência ordenativa da linguagem, e associar ao polo do mythos o caráter poiético da manifestação simbólica.

Tanto mythos como lógos indicam processos de comunicação em que algo vem a ser exposto (através da fala). O manifesto no processo do légein chega à patência como algo que se explana, que se "deita à vista" numa certa ordem. Já mythos evoca um outro aspecto da linguagem: assinala o dizer enquanto gesto que se desfecha na operação dramática de um sentido: é palavra que acontece, palavra "acontecedora" 23 . Reporta-se, pois, à capacidade humana de produzir, no campo comunicativo, a intuição do objeto visado... paralelamente à do enunciar enquanto tal. $\mathrm{O}$ sucesso do enunciar, que o constitui enquanto um fenômeno em si, é passível de iluminar-se correlata e simultaneamente à intuição do significado, graças à dýnamis do que Jakobson chamou de "função poética" da linguagem. Por outro lado, dá-se que a ordem do dizível não se cinge à mesma necessidade que rege o existente no campo da experiência onde a enunciação inscreve o dictum. (Posso falar que ontem cavalguei a lua... Meu ouvinte escapa do engano, mas não deixa de conceber a idéia enganosa. Até para a rejeitar, tem de erigi-la em matéria intuitiva... $)^{24}$. E porque o dizível ultrapassa as proporções do campo da experiência, abre-se, no horizonte desta, uma perspectiva capaz de transfigurá-la. Assim, em sentido fenomenológico, o dizer do mythos tem sempre a qualidade de um lógos poietikós... tanto mais efetiva quando operacionaliza a Gedankenexperienz de um evento de outro modo irrealizável ${ }^{25}$.

Em suma, creio que pode ser útil um emprego confessamente arbitrário de lógos e mythos para a designação de dimensões, tanto da linguagem como da produção simbólica em geral, que não se excluem mutuamente, mas se destacam ainda assim: distinguem-se conforme os aspectos dominantes nos paradigmas ligados a um e outro campo.

Mas a retomada proposta exige algumas renúncias: com isto não se estabelece uma separação rigorosa entre os dois domínios assinalados; não se pretende que a passagem de um a outro seja uma transcendência, um salto evolutivo do espírito humano, com a franquia do acesso ao conhecimento "válido" sobre o homem e o mundo, barrado enquanto se permanecia "do outro lado"; não se postula que esta passagem seja localizável num ponto único da história humana, por façanha de uma cultura mais afortunada. 


\section{Devo explicar minha insistência em recorrer a esses termos (mythos, lógos).}

Uma coisa é certa: seja qual for o período de sua história semântica, no grego antigo, que se queira destacar, mythos jamais corresponde precisa e exclusivamente ao que hoje se entende por "mito".

Mas também a palavra idéia, tal como existe e se compreende nas línguas modernas a cujo vocabulário se incorporou, de modo algum equivale ao que Platão entendia por idéia; e muito menos ao que o termo significava para o homem comum da Grécia Antiga. No pensamento ocidental, ela mudou de sentido várias vezes (desde a Antiguidade, aliás): talvez se possa reconhecer estilos e distinguir sistemas filosóficos pelas diferenças de emprego técnico desse termo... Ainda assim, a noção tem um poder comunicativo inegável e presta-se a discussões fecundas. Os diálogos que travam os pensadores a propósito de seu significado, sempre a renovam.... Isto quer dizer que ela tem um rendimento cognitivo constante: tanto que continua a ser empregada como um instrumento teórico, por sinal difícil de dispensar... Por outro lado, por mais que se tenha alterado a noção de idéia, sua recriação platônica ainda se apresenta como um momento decisivo na história do conceito.

Creio que é útil estudar a evolução semântica do termo mito, não porque haja um momento perfeito em que essa palavra tenha tido (apenas) um sentido exato a recuperar e aplicar precisamente, mas porque a apreciação de sua história pode sugerir novas aproximações a algo que ela tanto indica quanto encobre. Isso não obriga a uma fidelidade absoluta ao(s) sentido(s) do étimo. Pelo contrário, a construção (ou reconstrução) de um conceito frequientemente exige que se dispense ao vocabulário empregado nesse trabalho um tratamento algo "excessivo": exige que se altere e até que se violente o seu uso primeiro, ou comum...

Já estou pressupondo, é claro, que o conceito usual de mito não é suficiente para fins analíticos. Vejamos... Seguindo as indicações de Vernant e Detienne, destaquei dois momentos da trajetória semântica em que mythos avançou rumo ao sentido atual de mito: primeiro, o momento em que passou a rotular variados dizeres de uma tradição heteróclita, refletindo uma exclusão... e, na raiz desta, uma oposição... que pode ser arbitrariamente indicada com a fórmula convencional do binômio mythos x lógos ${ }^{26}$; depois, destaquei o momento - mais decisivo - em que a prática dos mythologoí identificou (operacionalmente) o mythos como uma classe de narrativa. Assim se constituiu um molde categorial básico que resultou, através de uma rica história, no conceito moderno de mito.

Neste caso, também é preciso ponderar a aplicabilidade do instrumento. Pode ele ter valor antropológico, isto é, empregar-se proficuamente na comparação transcultural?

Sim e não.

O conceito de mito não será muito útil se for deixado intacto, mantido como está, com o pressuposto secreto de que todas as tradições correspondem à nossa. Mas acredito que ele é suscetível de ajuste, capaz de transcender limites originais, ganhando elasticidade e pondo-a à prova seguidamente.

É inegável que narrativas categorizadas como "mitos" pelos estudiosos, recolhidas em diferentes sociedades, a distâncias que tornam impensável a difusão, ao ser comparadas entre si mostram correspondências estruturais, traços comuns, semelhanças significativas, embora procedam de diferentes culturas. Mas até onde a comparação pode ir? Quais os limites de sua pertinência? Qual o seu alcance? Que ajustes a comparação tem de fazer, para definir os campos entre os quais projeta sua ponte? Como se dá sua equiparação?

Enquanto o estudioso consulta apenas seu próprio entendimento, os problemas não se mostram muito aflitivos. Ele pode refugiar-se no senso comum dos leitores educados 
numa tradição onde é matéria de fé que "mito se reconhece logo". A dificuldade aparece quando o antropólogo decide levar em conta os conceitos e classificações de seus "fornecedores".

De acordo com G. S. Kirk (Kirk, 1970), "Myth belongs to the more general class of traditional tale”. Walter Burkert (Burkert, 1979) acolheu esta indicação e buscou torná-la mais precisa, dizendo que o traditional tale a ser identificado como mito sempre concerne a "something important, serious, even sacred". Mas note-se... indicativos dessa atribuição de relevância podem aparecer ou não em traços formais que orientem "qualquer leitor, no mundo inteiro". O mais comum é que não apareçam...

Tive o privilégio de ser educado entre grandes contadores de histórias. Lembro-me com saudade de velhas tias que me narravam contos "do arco da Velha"... e também milagres, façanhas, martírios de santos. Para a criança que então eu era, a diferença básica é que minhas tias veneravam os santos: com uma fé que me transmitiam, confiavam neles e em suas proezas. Contavam, também, "histórias de assombração", muito convincentes pelo medo gostoso que inspiravam... e quase sempre davam crédito a esses casos. Pois bem... Penso que os etnógrafos, às vezes, têm menos pistas do que eu teria para distinguir o acreditado e o desacreditado, o crível e o incrível, o "decisivo para o mundo" e o inessencial, se minhas tias não me informassem sobre sua avaliação... Mas devo dizer que as coisas não eram tão simples para mim: a avaliação delas não correspondia, por exemplo, à de meus pais, que acreditavam nos santos, porém não davam muito crédito a sua legenda áurea local.

Sofri ainda a interferência de um delicioso elemento complicador. Foi uma coisa que, a princípio, me trouxe muita perplexidade, porém terminou sendo instrutiva: a irrupção, no meu pequeno círculo, de uma senhora, vizinha nova, aparentada a meu pessoal, que era lindamente mitômana e falava com arte de seus encontros (em sonhos, ou mesmo na vigília do cotidiano) com bem-aventurados, anjos e almas do outro mundo. Suas histórias tinham o mesmo grau de verossimilhança que as narrativas hagiográficas de minhas tias; mas estas ficavam furiosas com a prima remota e com a óbvia preferência que eu lhe dava, em termos de atenção. O argumento com que fulminavam a bela mitômana era ad hominem (ou antes ad mulierem): - Arre, vejam só quem quer passar por santa! -... No entanto, embora a prima também não me transmitisse a impressão de pessoa ascética, a meus olhos isso não a desacreditava...

Ora, aí está: imagino um antropólogo estrangeiro, de uma cultura bem diferente, trabalhando em minha cidade natal, nessa época, ou mesmo hoje. Ele poderia recolher histórias como a da Gata Borralheira, a de Sansão e Dalila, a da Mãe de São Pedro, a do Cancão de Fogo, a de São Jorge e o Dragão, a da Mulher que bateu na Mãe e virou Cachorra, a do Abandono de Omolu, a do Sermão de Santo Antônio aos Peixes, a da Fuga de Iansã, a dos Pares de França, a da Cura da Burrice do Padre Antônio Vieira, a de Davi e Golias, a do Pavão Misterioso, a dos Portugueses que apanharam de mulheres no Paraguaçu etc. Algumas dessas histórias, ainda hoje, merecem acatamento especial na comunidade onde circulam; outras são aí consideradas fantasiosas, inacreditáveis (como é o caso do conto da Mãe de São Pedro). Ele poderia também recolher casos: relatos concernentes a acontecimentos não necessariamente remotos, mas sempre considerados memoráveis, muitos deles acatados como exemplares, muitos classificados como apenas esquisitos; e causos, estima- 
dos inteiramente inverossímeis, mas recontados com enorme gosto; além de romances (em versos) guardados de memória, cantados ou não. Poderia encontrar-se com minha prima, ou com uma outra pessoa igualmente dotada... Abstraindo os contextos institucionais a que essas narrativas pudessem remeter, e considerando só o seu aspecto formal, ou antes sua matéria fantástica e sua estrutura (as suas interrelações, no corpo da tradição na qual vivem), é possível que meu etnógrafo imaginário imediatamente os alinhasse, tutti quanti, sob a mesma rubrica. Depois, ao dar-se conta de sua diferente apreciação pela comunidade, ele buscaria, sem dúvida, separá-los em grupos distintos... Pois bem: suponha-se que, tendo advertido essa diferença por declarações explícitas, mas só em algumas instâncias, o pesquisador tentasse inferi-la em outras, segundo critérios formais. Não creio que tivesse grande êxito... Agora imagine-se que, num segundo momento, ele decidisse orientar-se de maneira rigorosa pela indicação dos informantes, destacando, entre todos, um grupo de narrativas que eles declarassem relacionadas a "something important, serious, even sacred". Caso quisesse atender aos critérios nativos, não teria uma classe única.

Por outro lado, de uma coisa estou certo: ao conferir a relação dos contos ditos "sem importância", classificados de "conversa pra boi dormir" ou até rotulados de "besteiras", esse antropólogo sentiria que alijava material muito valioso para sua tentativa de interpretação do pensamento da comunidade pesquisada, de sua visão de mundo. Logo verificaria também que não é muito fácil aferir o grau de importância atribuído a narrativas, tradicionais ou não, pelo povo de minha terra... um povo que preza a ficção de uma maneira singular.

Já vi uma pequena multidão reunida à volta do único televisor de uma rua, tensa e ansiosa, esperando um beijo de um casal de atores. Quando o beijo aconteceu, houve foguetório, batuque, uma festa ${ }^{27}$. Todos sabiam que se tratava de ficção, que os personagens mostrados na tela do vídeo não existiam realmente, que os atores só os "viviam" no momento da representação, que era tudo "de mentira"... mas nem por isso o animado público considerava desimportante o acontecimento da telenovela, pelo menos enquanto durou. As pessoas que choraram, pularam, dançaram e se beijaram por conta daquele esperado beijo obviamente não achavam trivial o que eles mesmos classificavam como "de mentira".

Telenovelas são, digamos, "mitos" efêmeros: em um ano, aqueles espectadores ardorosos já tinham esquecido o drama que tanto os comoveu; passado algum tempo, a atriz que fez a "mulher má" da história até poderia ir ao bairro onde se deu o episódio narrado acima, sem muito risco de levar uns tapas. Porém algumas obras do gênero duram mais na lembrança dos espectadores... Meu etnógrafo bem poderia recolher, em meio a seu material, um enredo (já transformado) de uma antiga novela de tevê, ou até de rádio.

Bom, vamos supor que ele formasse o seu corpus "às cegas", num primeiro momento... (seria bem doido!) e só depois fizesse a classificação segundo os critérios nativos. Por fim, imagine-se que ele misturasse tudo de novo e mandasse os resumos traduzidos a leitores de diferentes países onde a língua e a cultura de minha gente fossem desconhecidas, pedindo-lhes para classificar essas histórias, para reconhecer as que seriam mitos. Pode-se garantir que os resultados seriam concordes, exatos? Com que tipo de exatidão?

O exemplo concerne a um repertório que, comparado com muitos outros, pelo mundo afora, pode até ser considerado simples... No já citado artigo em que discute "les frontières du mythe", lembra Vernant que Pierre Smith (Smith, 1980), trabalhando com um corpus de mais de mil "contos orais" de Ruanda, distinguiu oito gêneros, ou subgêneros, demarcados por traços estilísticos próprios a cada um deles... ${ }^{28}$ Oito gêneros... "dont aucun ne pourrait 
être rangé dans la catégorie du mythe, si on entend par là un genre spécifique". Claude Calame (Calame, 1988) já registrava como um dado de consenso entre os estudiosos a inevitável conclusão a que repetidas constatações deste tipo os têm levado: "C'est désormais chose connue que dans les multiples classifications de récits que nous offrent des cultures différentes de la nôtre, aucune catégorie ne correspond à nôtre concept de mythe. Autant des cultures, autant des catégories différentes; autant de taxinomies, autant de 'découpages' narratifs de la 'matière' narrative d'une communauté culturelle, selon les critères les plus variés".

Ainda assim, acredito que o conceito de mito continua tendo importância e valor transcultural.

Não em absoluto, claro. Não é possível dizer que o mito, tal como o concebemos a partir da tradição clássica, existe no mundo inteiro, e em todos os lugares se mostra identificável num primeiro relance, "por qualquer leitor".. ou qualquer ouvinte.

Penso que é a própria comparação transcultural que deve redesenhar o conceito de mito, para uso antropológico. Isto sem dúvida será útil também aos helenistas, que cada vez mais recorrem à antropologia...

\section{Notas}

1 - Entenda-se aqui "helenismo" no sentido mais amplo do termo: no sentido em que o empregava Tonnybee (1969), por exemplo, referindo-se não apenas à cultura das sociedades gregas, mas também a Roma e a civilização romana, que compreendia também nessa designação.

2 - Mas o critério é falho. Em nosso meio, por exemplo, os símbolos cristãos constituem uma referência inevitável, também para agnósticos e ateus.

3 - Mesmo no caso de Ovídio, seria uma simplificação muito grande supor que ele não dava crédito algum aos mitos "ficcionalizados" nos seus versos. A propósito, veja-se o pequeno mas substancioso artigo de Franz Graf (Graf, 1988, p. 57-70).

4 - Refiro-me ao fragmento nietzscheano Die Boesen, cuja primeira redação data de 1884: Der Dichter, Der lügen kann / Der kann allein Wahrheit reden. Um tanto alterado, este fragmento incorporou-se mais tarde ao Canto da Melancolia do Zaratustra, IV.

5 - Quanto a isso, baste lembrar a importância que assumiram na obra de Hegel as figuras de Édipo e Antígona. Steiner (op. cit.) compara a presença de Antígona na Fenomenologia do Espírito à de Homero em Platão e à das óperas de Mozart em Kierkegaard - exemplos máximos de integração de obras de arte em discursos filosóficos. Hegel ocupou-se muitas vezes do drama sofocleano Antígona, destacadamente na Filosofia da Religião, na Estética e no seu curso de História da Filosofia. Édipo teve também um lugar muito significativo no pensamento hegeliano: destacadamente no cap. VI da Parte II da Fenomenologia do Espírito. Aliás, é sabido que Hegel planejava traduzir o Édipo em Colono.

6 - No entanto, o mito "grego" que ele consagra, que ele produz de um novo modo, nada tem de inocente. Sob o olhar criativo do Psicanalista, rompe com a pureza da forma trágica. O sentido que assume então é o de uma confissão tenebrosa, a mais difícil de todas: trata-se de uma verdade oculta que vem ao palco para desiludir, numa revelação decisiva e quase insuportável, só por isso velada em seu próprio corpo fantástico. 
7 - "Qualquer que seja nossa ignorância da língua e da cultura da população onde foi colhido, um mito é percebido como mito por qualquer leitor no mundo inteiro..." Confesso meu ceticismo: não estou muito seguro disso. Hoje, creio que a maioria dos antropólogos comparte esta insegurança. Perguntei ao autor de um livro chamado "Mitos e outras narrativas Kamayurá"(Agostinho, 1974) como é que ele distinguia os "mitos" da sua coletânea das "outras narrativas". Ele respondeu-me que nem sempre consegue distinguir, não está seguro da distinção. Fiquei aliviado... É que histórias por mim recolhidas em comunidades onde pesquisei deixaram-me na mesma dúvida. Tenho notado que isso acontece com muita gente boa. O alívio perverso que a constatação me traz vem de saber que não estou exposto sozinho à ironia de um conselho lacônico: - "Escreva a qualquer leitor do mundo!" - A célebre sentença de Lévi-Strauss encontra-se no seu famoso artigo "The Structural Study of Myth", depois transformado no cap. XI da Antropologia Estrutural. Cito da tradução brasileira, p. 242.

8 - Num conhecido artigo, depois de uma citação da desfiadora sentença de Lévi-Strauss, M. Detienne lembrou a declaração oposta de outro grande mitólogo: Dumézil confessou ter passado a vida toda tentando compreender a diferença entre um conto e um mito... Reporto-me à trad. Portuguesa do verbete "Mtio/Rito", de autoria de Detienne (Detienne, 1967), no vol. XII da Enciclopédia Einaudi, p. 58-74.

9 - Cf. Lévi-Strauss, 1966 Quatrième Partie ("Les instruments de tenèbre”), em especial o cap. II, "L'harmonie des sphères", p. 364-408. As citações a seguir remetem às páginas 406-8.

10 - Lévi-Strauss presume, portanto, que apenas a civilização ocidental produziu filosofia e ciência, conhecimento positivo.

11 - Ou seja, tão pouco no Ocidente quanto na América Indígena.

12 - "Mitologia e Ritual". Cf. Sousa, 1973, p. 95-122.

13 - Remeto à edição referida apud E. de Sousa, op. cit., nota 3. [Cf. a tradução brasileira (Jaegger, 1973) às páginas 131-2]. Jaegger prossegue: "sie würde mitten durch das homerischen Epos hindurchgehen, doch die Durchdringung rationaler Elemente mit dem 'mytischen Denken' ist dort noch so eng, dass eine Loslösung kaum mögliche sein wurde." Segundo nota ainda o autor de Paideia, "es ist nicht leich zu sagen woduch sie die Lehre des homerischen Dichters, dass Okeanos der Ursprung alles Dinges sei, von der Thales unterscheidet, für dessen Ansicht vom Wasser als Urprinzip der Welt anschauliche Vorstellung des unerschöpflichen Weltmeeres zweifeloss mitbestimmende war (...) Der Beginn der wissenschaftlichen Philosophie fällt also weder mit dem Anfang der rationalen noch mit dem Ende des mythischen Denkens zusammen."A cita de Homero remete à $I l$. XIII, 201 e 246.

14 - Ver o ensaio "Mito pré-helênico e mitologia grega". Sousa, op. cit., p. 123-146. A cita remete à p. 126.

15 - É o que ele declarou em entrevista a R. Bellour, 1967.

16 - A crítica desta atitude se acha muito bem feita por M. Detienne no capítulo de Dionysos mis à mort que tem o título irônico de "Les Grecs ne sont pas comme les autres".

17 - Só então o mito se mostra "delimité et reduit à lui-même, como diz Vernant (Vernant, 1996). Ou seja, como evidenciou Christian Jacob (Jacob, 1994): aparece então o mito já despido de sua eficácia política e social, (sem a função que tivera no século V, de propaganda das cidades gregas e das famílias aristocráticas); sem álibi estético ou literário; 
sem mais integrar-se num quadro global de interpretação alegórica; e já dissociado do conato de uma busca do maravilhoso (que o revestia na obra dos paradoxógrafos). "Un mythe desengagé, donc" - Vernant resume - délié du littéraire, séparé de l'histoire, échappant aux enjeux idéologiques et locaux de la Grèce des cités..." Mas claro está que ele ainda cumpre uma função ideológica: “À l'organization géopolitique qui fait de Rome la métropole d'un Empire où la Grèce est réduite à la condition de provinces, le mythographe substitue un espace culturel, balisé et organizé par la langue et la littérature grecques, où les héros et les dieux investissent le monde méditerranéen..." Desse modo, conclui C. Jacob, "la smythologie grecque, dans sa forme substantielle, est donnée comme mémoire culturelle à tous les peuples de l'Empire”. Sobrevivendo ao Império Romano, a mitologia grega viria a ser a memória cultural do Ocidente... em em grande medida determinou a maneira como os ocidentais, seus herdeiros, viriam a pensar sobre os mitos de outros povos.

18 - E suscitou ainda uma (sub)espécie de mítica: uma mitologia... no sentido barthesiano do termo.

19 - Refiro-me a uma pequena epidemia de estudos "antropológicos" sobre mitos gregos, apresentados como exercícios de análise estrutural segundo a evidência inquestionável de belas colunas, em quadros traçados a capricho. Não quero generalizar, pois seria injusto. Foram maravilhosamente enriquecedoras para a Altertumswissenschaft incursões feitas na seara clássica por antropólogos especializados no estudo de culturas bem diversas. Vou logo ao exemplo máximo: a grandiosa contribuição de Lévi-Strauss. O artigo (já citado aqui) em que ele lançou sua proposta de uma análise estrutural dos mitos, embora muito criticada pelos helenistas em função da abordagem aí feita do mito de Édipo, também no seu meio repercutiu de forma positiva. Não há dúvida de que a obra levistrausssiana, como um todo, foi uma rica fonte de inspiração e teve um poderoso impacto nos estudos clássicos, influenciando de maneira profunda alguns dos maiores especialistas da atualidade neste domínio. Lévi-Strauss continua sendo um guia para importantes helenistas... Mas há boas razões para reclamar de abusos decorrentes de uma aplicação pouco refletida de métodos "estruturalistas", e de uma certa ingenuidade preguiçosa que sua proposição pareceu justificar... quando, por exemplo, muitos passaram a considerar dispensáveis o cuidado com os testemunhos, a crítica dos documentos, o exame dos registros... porque, de acordo com o novo dogma, nenhum arranjo ou transposição afetaria "no essencial" a natureza da mensagem mítica: por suposto, qualquer resumo serviria para estabelecer uma versão a ser finalmente reduzida ao esqueleto de um esquema sucinto. Uma certa nonchalance com relação ao documento quase se tornou sinal de perícia... Ora, do ponto de vista do helenista, esta nonchalance é suicida. O trabalho de interpretação de um mito começa no tratamento crítico dos testemunhos, na pesquisa das fontes, na produção crítica dos dados. A menos que se queira trabalhar no escuro, sujeito a miseráveis enganos.

20 - Como bem mostrou Christian Jacob (Jacob, 1994), ao erigir-se a chamada "mitologia grega", os mitos helenos já tinham perdido as funções sociais e políticas que tinham em seu contexto originário, e outras "aplicações" posteriores (como as que lhes deram os poetas alexandrinos, os paradoxógrafos et alii). No mundo romano imperial, os mitos gregos assumiram outro valor: o de referenciamento cultural: "A l'organisation géopolitique qui fait de Rome la métropole d'un Empire où la Grèce est réduite à la condition de provinces, le mytographe substitue un espace culturel, balisé et organisé par la langue et la littérature grecques, où les héros et les dieux investissent le monde 
méditerranéen... la mythologie grecque, dans sa forme substatielle, est donnée comme mémoire culturelle à tous les peuples de l'Empire."

21 - Os esforços da alegorese apenas constituem a superfície mais visível de uma reflexão que se embebeu dos mitos antigos ao tomá-los por objeto. O estranhamento crescente que o esboço de um primeiro "saber dos mitos" já pressupõe foi paralelo a uma impregnação. Assim, o evemerismo, por exemplo, é sem dúvida uma racionalização. Tornado método, obedece a um contato regulador, de controle e correção da mítica. Mas um de seus primeiros efeitos foi reconciliar com os mitos os homens cultos da Grécia e de Roma que já se sentiam incapazes de aceitá-los simplesmente, mas não os queriam rechaçar "feito um monte de mentiras" (cf. Seznec, 1977, p. 122). Deste modo, a doutrina evemerística colaborou para a preservação das "velhas histórias", muito desacreditadas no ocaso de uma religião que fora seu ambiente natural. O evemerismo assim estimulou a recoleção mitológica. Depois, ele teria consequiências mais impactantes. No início da era cristã, a acolhida entusiástica da tese evemerista por parte de apologetas do cristianismo, Padres da Igreja, fundava-se na idéia de que ela propiciava um claro desvanecimento da ilusão pagã... Ainda nesse terreno, porém, essa tese foi uma arma de dois gumes. Mesmo combatendo a crença nos mitos antigos, ajudou a conservá-los, remodelados. Segundo observa o citado Seznec (p. 220), rapidamente o evemerismo perdeu "o veneno apologético" e converteu-se em auxiliar da investigação histórica: logo passou-se a indagar quando teriam vivido os grandes homens convertidos em deuses pela ingenuidade do povo, e à tentativa de situá-los em épocas definidas nos anais da humanidade. "Auxiliar da investigação histórica", diz Seznec; traiçoeiro, acrescento. Segundo o próprio Seznec lembra (p. 21), já na Crônica de Eusébio se acha esboçado o paradigma dos "sincronismos grosseiros" que, desde a época de Abraão até a era cristã, concentram em alguns períodos axiais todos os sucessos decisivos e todos os grandes personagens da história humana. É o esquema das "concordâncias", que se transmite à Idade Média através de São Jerônimo, e obtém espantoso sucesso. Podem citar-se em testemunho disso a obra de Paulo Orósio, a de São Isidoro de Sevilha, a de Pedro Comestur e inúmeras outras... É minha tese que deste modo se constrói o modelo das "meta-narrativas" que sucessiva e variadamente vêm a constituir o campo ideológico da História Universal. Por outro lado, ainda na Antigüidade, a mitologia greco-romana sofreu uma outra lenta transformação que a atingiu em seu todo e abriu caminho a significativas alterações. Seznec acentua a complexidade da evolução que resultou na identificação de deuses e astros, a partir de correspondências desde muito reconhecidas, e tornadas então definitivas num contexto marcado por profundas elaborações sincréticas. Essa identificação deu lugar a uma nova teologia, quando, como diz Seznec (p. 41), "a imaginação mítica dos gregos, que criara os deuses na terra, acabou por encontrá-los no céu..." Acho preferível descrever esse desenvolvimento operado no interior da "mitologia clássica", no ambiente helenístico e romano, como um recorte universalista que erigiu um dos códigos da mítica grega em eixo decisivo -, que o "axializou", produzindo no respectivo sistema uma macro-transformação. A mitologia afetada por este desenvolvimento veio a tornar-se matéria de uma poderosa bricolagem, a qual originou nova construção, também mítica, já muito depois do ocaso do helenismo. O citado Seznec dá um belo painel do processo, que teve lugar na Idade Média européia, com emprego desse e de outros materiais, de origens diversas, quase sempre também já "bricolados". O trajeto acidentado de tal construção resultou no sistema da astrologia européia. Sob o influxo da gnose, 
e com o intrincado concurso de vários afluentes de um rico sincretismo, formou-se ainda outra vertente, que, a comunicar-se com esta em diferentes pontos, veio a desembocar, através de caprichosos meandros orientais, no sistema da alquimia. Assim, os mitos greco-romanos forneceram a matéria prima de considerável produção mítico-mágica, na Idade Média, no Renascimento, e ainda além... ao tempo em que, por outro lado, a mitologia clássica também impregnava a erudição, a arte e a literatura do mundo ocidental. A correnteza da tradição diversifica-se em múltiplos cursos, que em parte fluem subterrâneos... Nos domínios da feitiçaria popular, da magia (astrológica, lapidária, alquímica etc.) e em outros espaços (como na hagiografia, na demonologia, nos vastos campos de um folclore devoto), um trabalho "arqueológico" facilmente descobre muitos elementos do thesaurus mítico da Antigüidade, mantidos, nessa nova existência, ainda em ligação com o universo religioso. Esta ligação se atenua e por fim chega a dissolver-se no fabulário e na crônica onde esses ingredientes de novo se reagrupam... Assim, em diversos pontos da tradição do Ocidente, os estudiosos podem assinalar exemplos de "últimas" transformações romanescas de mitos antigos, bem como de sua alteração segundo os esquemas de uma elaboração histórica... retrospectiva, ou prospectiva... para o dizer nos termos de Lévi-Strauss (Lévi-Strauss, 1977).

22 - Detienne, op. cit. supra, p. 69.

23 - "Deitar", como se sabe, é um dos sentidos do verbo légein. Refiro-me também a uma "vista", digamos, "platônica"... acesa na estrutura cognitiva da língua grega muito antes de Platão. A propósito, evocarei primeiro o famoso comentário de M. Heidegger ao frag. 50 de Heráclito (trata-se de uma conferência pronunciada em 4 de maio de 1951 e publicada pela primeira vez nesse mesmo ano, em uma coletânea em homenagem a Kurt Bauch; o estudo foi incorporado ao livro Vortäge und Aufsetze com o título de "Lógos". Veja-se a tradução brasileira de Ernildo Stein, in J. Cavalcanti de Souza, 1978, pp. 111123; a cita a seguir remete à p. 112 ): "Quem ousaria negar que, na linguagem dos gregos , desde cedo légein teria significado falar, dizer, narrar? Mas também significa, tão cedo, e ainda mais originariamente, e por isso desde sempre... o que entendemos como o legen do alemão, que soa parecido: deitar e estender adiante. O que impera aqui é o recolher, o legere do latim, como colher no sentido de ir pegar e recolher. Légein significa propriamente o pensar e apresentar o que recolhe a si e às outras coisas." A partir daí, Heidegger desenvolve uma reflexão luminosa sobre o sentido de légein e lógos. Quanto ao que digo sobre "vista... na estrutura cognitiva da língua grega", remeto ao belo estudo de Eudoro de Sousa sobre "O Mito de Psiquê e a Simbólica da Luz" (Souza, 1973, p. 213239). Em suma, o légein assinala o processo em que se "deita à vista” (da inteligência) alguma coisa, com atenção que permite eleger... Walter Otto (Otto, 1987, p. 26) considera mais fundamental este traço semântico que a idéia (derivada) da recolha: "Der usrprüngliche Begriffe ist der der 'Auslese' (und daher dann des Sammelns) also des Achthabens, Bedenkens, Rücksichtnehmens, wie das Griechische zeigt und aus dem Lateinische namentlich neglegere als Gegensatz zum legere, legio, religio u. a. m." Quanto a mythos, recordo o que diz Detienne (Detienne, 1987, p. 26): trata-se de uma "palavra gesto"... Penso também no forte colorido gestual que esta palavra tem em Homero: o mythos se enlaça na "cadeia de acontecimentos" que, como diz Bruno Snell, configura o mundo homérico. Por isso mesmo, por causa da vocação de acontecer que a caracteriza, o sentido básico da palavra mythos, segundo nota Walter Otto (op. cit.) “ist ganz objektiv: das Wirkliche und Tatsächliche (im Wort, natürlich!). 
24 - A propósito, ver Serra, 1991, p. 106.

25 - Se o visado na intuição manifesta no discurso é suscetível de realizar-se mediante um investimento previsto, o "modelo de realidade" que assim se imagina vem a ser um projeto; se o intuitum corresponde a dados atuais (vividos) da experiência concreta, os modelos correspondentes cifram uma representação que a sintetizam numa forma objetiva. Mas tanto a Poesia quanto a Ciência (sua vizinha neste ponto) atestam que a Gedankenexperienz de um evento de outro modo irrealizável é capaz de dar sentido a experiências concretas. A meu ver, a operação da função poética não é privilégio exclusivo da linguagem verbal. Mesmo numa pintura figurativa, por exemplo, onde a representação parece ser o essencial (a ponto de tornar necessária a ironia do “ceci n’est pas une pipe"), o valor que estabelece a diferença estética enquanto efeito de arte corresponde, em grande medida, à própria pintura, ao próprio da pintura.

26 - Já esclareci que não volto à oposição de mythos e lógos tal como ela aparece num momento teórico que a consagrou. Estou simplesmente verificando que um passo importante na formação do sentido atual de "mito" pode ser assim simbolizado.

27 - Como depois eu soube, fazendo uma rápida etnografia, os foguetes e tambores já tinham sido providenciados havia uma semana, enquanto a expectativa cultivada pela direção do drama chegava a uma iminência crescente.

28 - Esses traços estilísticos são, evidentemente, marcas êmicas diacríticas, signos da classificação nativa. Trata-se de uma taxinomia caprichosa.

\section{Referências bibliográficas}

AGOSTINHO, P. Mitos e Outras Narrativas Kamayurá. Salvador: EDUFBA, 1974.

BELLOUR, R. Entretien avec Claude Lévi-Strauss. Les Lettres Françaises, n. 1. 1165, jan. 1967, p. 1-7.

BURKERT, W. Structure and History in Greek Mythology and Ritual. Berkerley: L. A. University of California Press, 1979.

CALAME, C. (Ed.). Métamorphoses du Mythe en Grèce Ancienne. Genève: Labor et Fides, 1988.

CAVAlCANTI DE SOUZA, J. (Ed.). Os Pré-Socráticos. São Paulo: Editora Abril Cultural, 1978

DETIENNE, M. L'Invention de la Mythologie. Paris: Gallimard, 1981.

. Dionysos mis à mort. Paris: Gallimard, 1986.

“Mito/Rito”. Encicolopédia Einaudi, XII: 58-74. Porto: Casa da Moeda,1987.

GRAF, F. “Ovide, les Métamorphoses et la Véracité du Mythe”. In: CALAME, C. (Ed.). Métamorphoses du Mythe en Grèce Ancienne. Genève: Labor et Fides, 1988.

HEIDEGGER, M. Lógos. In: SOUSA, J. Cavalcanti de et al. Os Pré-Socráticos. São Paulo: Abril, 1978.

JACOB, C. “L’Ordre Genéalogique entre le Mythe et l’Histoire”. In: DETIENNE, M. (Org.). Transcrire les mythologies. Tradition, écriture, historicité. Paris: Albin Michel, 1994. p. 169-202. 
JAEGGER, W. Paidéia. São Paulo: Martins Fontes, 1963.

JAKOBSON, R. Lingüística e Comunicação. São Paulo: Cultrix, 1974.

KIRK, G. S. Myth: its meaning and function in ancient and other cultures. C.U.P., 1970, LÉVI-STRAUSS, C. Du miel aux cendres. Paris: Plon, 1966. . Antropologia estrutural. Rio de Janeiro: Tempo Brasileiro, 1967.

. "Como eles morrem." In: Vários autores. Atualidade do mito. São Paulo: Duas Cidades, 1977. p. 91-103.

OTTO, W. "Der Mythos und das Wort" ("Mythe et Parole"). In: DAVID, Pascal (Ed./Trad.). Essais sur le Mythe. Paris: TER, 1987.

SERRA, O. J. O simbolismo da cultura. Salvador: Centro Editorial e Didático da UFBA, 1991.

SEZNEC, J. Los dioses de la Antiguedad en la Edad Media y el Renacimiento. Madrid: Taurus, 1985.

SOUSA, E. de. Dioniso em Creta e outros ensaios. São Paulo: Duas Cidades, 1973. . Mitologias. Brasília: Editora da Universidade de Brasília, 1980.

STEINER, G. Les Antigones. Paris: Gallimard, 1986.

TONYBEE, A. J. Helenismo, história de uma civilização. R. J.: Zahar, 1969.

VERNANT, J.-P. Frontières du Mythe. Paris: CLG, 1996.

SERRA, Ordep José Trindade. Antropology, mithology and its writing. Classica, São Paulo, 11/12, p. 15-36, 1998/1999.

\begin{abstract}
This article deals with the problem of the anthropological study of myth and discusses the applicability of the very notions of myth and mythology in cross-cultural studies. Particular attention is called upon the singularity of classic mythology as a historical construction, the outcome of mythography in classical tradition and scholarship. The necessity of a distinction between 'mythology' and 'mythics' (mythical tradition) is stressed out. The importance of the classical studies as a background of the anthropological theory is affirmed. Levi-Strauss assertion of the immediate recognizability of myth qua myth by readers from whatever part of the world is discussed, and his perception of Greek mythology compared with a classical scholar's, Eudoro de Sousa, equally interested in the detection of the particularity of Greek myth. In: order to clarify the meaning of "myth" as an anthropological category, the theoretical opposition of mythos and logos is also reconsidered.
\end{abstract}

KEYWORDS: myth; mythics; mythography; classical mythology; anthropology; helenism. 